\title{
PENGEMBANGAN MEDIA BOOKLET BERBASIS KEANEKARAGAMAN JENIS JAMUR MAKROSKOPIS
}

\author{
Linna Fitriani $^{1}$, Yuni Krisnawati ${ }^{2}$ \\ STKIP PGRI Lubuklinggau ${ }^{1,2}$ \\ linna.fitriani@yahoo.com
}

\begin{abstract}
ABSTRAK
Penelitian ini bertujuan untuk mengembangkan media booklet berbasis keanekaragaman jenis jamur makroskopis di Kota Lubuklinggau. Metode yang digunakan adalah metode Research and Development (R\&D), dengan dua tahap penelitian yaitu pembuatan media booklet dan validasi media booklet. Pengumpulan data menggunakan metode JAS. Validitas booklet dengan lembar kuesioner ahli media dan ahli materi. Respon keterbacaan dan kepraktisan menggunakan lambar kuesioner dosen dan mahasiswa, mengetahui respon keefektifan booklet dengan melihat hasil belajar dengan tes. Teknik analisis data menggunakan analisis Content Validity Ratio (CVR). Hasil penelitian tahap 1 diketahui ada 32 jenis jamur makroskopis, dari 4 kelas, 9 ordo, dan 16 famili. Jamur yang bisa dikonsumsi antara lain Auricularia-auricula-juda, A. cornea, Schizophyllum commune, Lentinus strigosus, L. triginus, Favolus brasiliensis, F. tenuiculus, Pleuretus ostreatus, Agaricus silvaticus, Marasmius oreades, Tremella mesenterica, Cookeina sulcipes, dan C. tricholoma. Sedangkan yang berpotensi sebagai obat yaitu Cordyceps militaris dan Coprinellus disseminatus, dan jenis jamur beracun adalah Chlorophyllum molybdites. Hasil analisis dan validasi media booklet masing-masing kriteria mendapat nilai CVR 1,00 dengan keterangan valid atau layak digunakan. Data angket dosen dan mahasiswa untuk kemenarikan rata-rata 3,3 dikategorikan menarik, untuk keterbacaan 3,1 dikategorikan baik, untuk efesiensi 3,5 dikategorikan sangat efisien, dan untuk kepraktisan rata-rata 3,7 dikategorikan sangat praktis. Simpulan, booklet yang dikembangkan dinyatakan layak digunakan, booklet dikategorikan menarik, keterbacaan baik, efisien serta praktis untuk digunakan.
\end{abstract}

Kata Kunci: booklet, jamur makroskopis, lubuklinggau, pengembangan

ABSTRACT
This study aims to develop a booklet media based on the diversity of macroscopic mushroom species in Lubuklinggau City. The method used is the Research and Development $(R \& D)$ method, with two stages of research namely making media booklets and validating media booklets. Data collection using the JAS method. The validity of the booklet with questionnaires for media experts and material experts. Response readability and practicality using a questionnaire questionnaire lecturers and students, knowing the response to the effectiveness of the booklet by looking at learning outcomes with tests. Data analysis techniques using content analysis Validity Ratio (CVR). The results of stage 1 research found that there were 32 types of macroscopic fungi, from 4 classes, 9 orders, and 16 families. Fungi that can be consumed include Auricularia-auricula-juda, A. cornea, Schizophyllum commune, Lentinus strigosus, L. triginus, Favolus 
brasiliensis, F. tenuiculus, Pleuretus ostreatus, Agaricus silvaticus, Marasmius oreades, Tremella mesentere, Cook and Cavina tricholoma While the potential as a drug are Cordyceps militaris and Coprinellus disseminatus, and the type of poisonous mushroom is Chlorophyllum molybdites. The results of the analysis and validation of the media booklet of each criterion received a CVR value of 1.00 with valid or proper information. The lecturer and student questionnaire data for the average attractiveness of 3.3 were categorized as attractive, for readability 3.1 was categorized as good, for efficiency 3.5 was categorized very efficient, and for practicality an average of 3.7 was categorized very practical. In conclusion, the booklet that was developed was declared suitable for use, the booklet was categorized as attractive, good legibility, efficient and practical to use.

Keywords: booklet, macroscopic mushroom, lubuklinggau, development

\section{PENDAHULUAN}

Taksonomi Tumbuhan Rendah (TTR) merupakan salah satu mata kuliah yang diajarkan di tingkat perguruan tinggi salah satunya di Program Studi Pendidikan Biologi STKIP-PGRI Lubuklinggau. Salah satu materi yang menarik untuk dikaji adalah fungi atau jamur. Berdasarkan hasil wawancara dengan beberapa mahasiswa diketahui bahwa mereka cenderung kesulitan menghafal tulisan-tulisan dan nama-nama ilmiah dari fungi. Mereka juga kesulitan mengklasifikasikan keragaman jamur, mendeskripsikan ciri morfologinya, serta kesulitan membedakan antara jamur yang bisa dikonsumsi, jamur sebagai obat dan jamur beracun.

Hal ini berpengaruh besar terhadap pencapaian ketuntasan materi jamur pada akhir perkuliahan. Menurut hasil penelitian Amri \& Jafar (2016), pengetahuan mahasiswa Pendidikan Biologi tentang nama-nama latin terlihat rendah karena persentase menjawab salah lebih banyak dari yang benar, disebabkan rumitnya pengucapan nama latin dan banyak pengelompokkannya, juga sebagian yang memiliki ingatan rendah jika tidak sering diulangi.

Berdasarkan hasil wawancara dengan dosen pengampu mata kuliah Taksonomi Tumbuhan Rendah (TTR) diketahui bahwa mahasiswa cenderung sulit menguasai materi fungi dikarenakan materinya cukup banyak. Cukup banyak karena jamur sendiri terdiri dari beberapa divisi, yang mencakup ciri morfologi, cara reproduksi, serta peranan. Minimnya LCD Proyektor juga menghambat penyampaian materi berupa gambar untuk mendeskripsikan ciri morfologi secara jelas.

Bahan ajar yang digunakan kebanyakan hanya berisi tulisan-tulisan dan gambar tak berwarna. Selain itu akses masuk untuk kegiatan praktikum di tempat yang memiliki banyak spesies jamur terbilang cukup mahal. Oleh karena itu, cara untuk mengatasi permasalahan-pemasalan yang ada adalah dengan mengembangkan media booklet untuk meningkatkan pengetahuan mahasiswa dengan cara yang efektif dan efisien. Dengan hadirnya media booklet keragaman 
jamur makroskopis diharapkan dapat membantu mahasiswa mengetahui klasifikasi, ciri-ciri morfologi, peranan, serta dapat membantu untuk mengenal jenis-jenis jamur lokal di Kota Lubuklinggau sehingga timbul rasa cinta untuk melestarikan dan mengembangkan di masa yang akan datang.

Penggunaan media sangat penting dalam proses pembelajaran, media yang tepat akan menarik keingintahuan anak dengan materi yang diberikan. Kata media berasal dari bahasa latin merupakan bentuk jamak dari medium, medius (Arsyad, 2009) yang secara harfiah berarti tengah, perantara atau pengantar. Media merupakan perantara untuk menyampaikan pesan Menurut Russell (1993) media merupakan saluran komunikasi.

Booklet adalah alat bantu, sarana, dan sumber daya pendukung untuk menyampaikan pesan yang sesuai dengan isi materi yang akan disampaikan. Booklet berisikan informasiinformasi penting. Isi Booklet harus jelas, tegas, mudah dimengerti dan akan lebih menarik jika Booklet tersebut disertai dengan gambar (Septiwiharti, 2015).

Dengan hadirnya media booklet keragaman jamur makroskopis diharapkan dapat membantu mahasiswa mengetahui klasifikasi, ciri-ciri morfologi, peranan, serta dapat membantu untuk mengenal jenis-jenis jamur lokal di Kota Lubuklinggau sehingga timbul rasa cinta untuk melestarikan dan mengembangkan di masa yang akan datang. Penelitian ini bertujuan menghasilkan media booklet berbasis keanekaragaman jenis jamur makroskopis di Kota Lubuklinggau.

\section{METODE PENELITIAN}

Metode yang digunakan dalam penelitian ini adalah metode penelitian dan pengembangan atau Research and Development (R\&D). Menurut Gay, dkk dalam Sugiyono (2012) teori R\&D memerlukan proses ilmiah (penelitian)untuk mengidentifikasi kebutuhan kemudian mengembangkannya hingga menjadi produk sesuai kebutuhan.

Penelitian terdiri dari dua tahap yaitu pembuatan media booklet berbasis keanekaragaman jenis jamur makroskopis di Kota Lubuklinggau dan validasi media booklet. Prosedur pembuatan media disusun berdasarkan keanekaragaman jenis jamur makroskopis di Kota Lubuklinggau Informasi hasil penelitian jenisjenis jamur

Data didapatkan dengan teknik JAS dan ditulis dalam lembar observasi untuk dijadikan bahan pembuatan media booklet. Validasi booklet dengan lembar kuesioner ahli media dan ahli materi. Respon keterbacaan dan kepraktisan menggunakan lambar kuesioner dosen dan mahasiswa, mengetahui respon keefektifan booklet dengan melihat hasil belajar dengan tes. Teknik analisis data menggunakan analisis Content Validity Ratio (CVR). 


\section{HASIL PENELITIAN}

\section{Pendataan Jenis-jenis Jamur}

Hasil penelitian ditemukan 42 jenis jamur makroskopis yang berhasil teridentifikasi sebanyak 32 jenis jamur makroskopis, dari 4 kelas, 9 ordo, dan 16 family. Jenis jamur pada ordo Agaricales ditemukan sebanyak 12 spesies. Ordo Polyporales ditemukan 8 spesies jamur, ordo Auricularia dan ordo Pezizales ditemukan masing-masing 3 spesies, ordo Aphyllophorales ditemukan 2 spesies. Kemudian ordo Russulales, ordo Tremellales, ordo Hypocreales, dan ordo Xylariales masing-masing ordo hanya ditemukan 1 spesies jamur makroskopis.

Berdasarkan pendataan jenis-jenis jamur yang ditemukan di sekitar kota lubuklinggau, diketahuJamur yang bisa dikonsumsi antara lain Auriculariaauricula-juda, A. cornea, Schizophyllum commune, Lentinus strigosus, L. triginus, Favolus brasiliensis, F. tenuiculus, Pleuretus ostreatus, Agaricus silvaticus, Marasmius oreades, Tremella mesenterica, Cookeina sulcipes, dan C. tricholoma. Sedangkan yang berpotensi sebagai obat yaitu Cordyceps militaris dan Coprinellus disseminatus, dan jenis jamur beracun adalah Chlorophyllum molybdites. persentase jamur makroskopis yang diperoleh sebagai berikut:

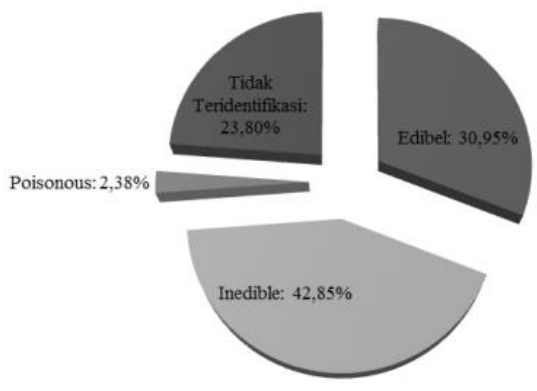

\section{Gambar 1. Persentase Jamur Makroskopis}

Berdasarkan Gambar 1 mengenai persentase jamur makroskopis di kawasan wisata Bukit Sulap sebanyak 10 jenis atau setara 23,80\% jamur makroskopis yang tidak teridentifikasi. Sebanyak 13 jenis atau setara 30,95\% jamur makroskopis yang bersifat edible (bisa dikonsumsi) sebagai bahan makanan sedangkan, jamur yang tidak bisa dimakan (inedible) dan dapat berpotensi sebagai obat herbal dan obat anti tumor sebanyak 18 jenis atau setara 42,85\%. Sebanyak 1 spesies atau setara 2,38\% jamur yang beracun (poisonous) karena berbahaya bagi manusia.

\section{Pengembangan Booklet Berbasis Keanekaragaman Jamur Makroskopis}

Media pembelajaran booklet berbasis keanekaragaman jamur makroskopis dikembangkan dengan diawali analisis terhadap kebutuhan mahasiswa, perumusan tujuan pembelajaran, rancangan/design berupa sketsa, pemilihan warna dan ukuran huruf. Dilanjutkan validasi oleh ahli yaitu ahli media, ahli 
bahasa, dan ahli materi serta keterbacaan, kepraktisan dan keefektifan media tersebut.

\section{Hasil Analisis terhadap Kebutuhan Mahasiswa}

Berdasarkan hasil wawancara dengan beberapa mahasiswa diketahui bahwa mereka cenderung kesulitan menghafal tulisan-tulisan dan nama-nama ilmiah dari fungi. Mereka juga kesulitan mengklasifikasikan keragaman jamur, mendeskripsikan ciri morfologinya, serta kesulitan membedakan antara jamur yang bisa dikonsumsi, jamur sebagai obat dan jamur beracun. Hal ini berpengaruh besar terhadap pencapaian ketuntasan materi jamur pada akhir perkuliahan. Menurut penelitian Amri \& Jafar (2016), pengetahuan mahasiswa Pendidikan Biologi tentang nama-nama latin terlihat rendah karena persentase menjawab salah lebih banyak dari yang benar, disebabkan rumitnya pengucapan nama latin dan banyak pengelompokkannya, juga sebagian yang memiliki ingatan rendah jika tidak sering diulangi.

Berdasarkan hasil wawancara dengan dosen pengampu mata kuliah Taksonomi Tumbuhan Rendah (TTR) diketahui bahwa mahasiswa cenderung sulit menguasai materi fungi dikarenakan materinya cukup banyak. Cukup banyak karena jamur sendiri terdiri dari beberapa divisi, yang mencakup ciri morfologi, cara reproduksi, serta peranan. mahasiswa perlu kelapangan untuk mengetahui keberadaan jamur makroskopis, tetapi akses masuk untuk kegiatan praktikum sering mengalami kendala dan terbilang cukup mahal. Mengembangkan media booklet bertujuan meningkatkan pengetahuan mahasiswa dengan cara yang efektif dan efisien

\section{Hasil Perumusan Tujuan Pembelajaran}

Mahasiswa dapat menguasai deskripsi/ciri, bentuk, cara hidup, perkembangbiakan, peranan dalam kehidupan serta taksonomi divisi Thallophyta, anak divisi Fungi kelas ascomycota dan basidiomycota dengan cara mengamati keanekaragaman jenis-jenis jamur dan deskripsi jamur makroskopis pada booklet.

\section{Hasil Design Kasar, Pemilihan Warna dan Huruf}

Rancangan kasar berupa cover depan dan belakang, kata pengantar, daftar isi , tinjauan materi umum, jenis-jenis jamur makroskopis beserta deskripsi khusus, dan di akhiri dengan biografi penulis. Huruf Yang Digunakan Adalah Times New Roman dengan Font yang disesuaikan dengan deskripsi.

\section{Validasi Booklet}

Hasil analisis data dan perhitungan hasil validasi media booklet yang telah dilakukan dapat diketahui bahwa masing-masing kriteria mendapat nilai CVR 1,00 dengan keterangan valid, sedangkan nilai rata-rata dari masing-masing kriteria yang diperoleh dengan perhitungan CVI juga menunjukan bahwa media booklet yang divalidasi valid dengan nilai CVI 1,00 yang berarti media booklet 
layak digunakan sebagai media pembelajaran pada materi fungi khususnya anak divisi Ascomycota dan Basidiomycota. Berikut hasil analisis data dari ahli media, ahli bahasa dan ahli materi dapat dilihat pada tabel 1 .

Tabel 1. Hasil Analisis Data dari Ahli Media, Bahasa dan Materi

\begin{tabular}{llccccc}
\hline \multirow{2}{*}{ No } & \multirow{2}{*}{ Kriteria Penilaian } & \multicolumn{2}{c}{ VALIDATOR } & \multirow{2}{*}{ CVR } & \multirow{2}{*}{ KET } \\
\cline { 3 - 6 } & & 1 & 2 & 3 & & \\
\hline 1 & Kesesuaian dengan perkembangan mahasiswa & 3 & 3 & 3 & 1 & Valid \\
\hline 2 & Kemampuan Memotivasi & Valid & 3 & 3 & 1 & Valid \\
\hline 3 & Kesesuaian dengan kaidah bahasa indonesia yang benar & Valid & 3 & 3 & 1 & Valid \\
\hline 4 & Penggunaan istilah Simbol/lambang & Valid & 4 & 3 & 1 & Valid \\
\hline 5 & Keterbacaan & Valid & 3 & 3 & 1 & Valid \\
\hline 6 & Desain & Valid & 3 & 3 & 1 & Valid \\
\hline 7 & Tampilan Fisik & Valid & 3 & 3 & 1 & Valid \\
\hline 8 & Cakupan Materi & Valid & 4 & 3 & 1 & Valid \\
\hline 9 & Keakuratan Materi & Valid & 4 & 3 & 1 & Valid \\
\hline 10 & Kemutakhiran Materi & Valid & 3 & 3 & 1 & Valid \\
\hline & & & & & $\mathbf{1}$ & Valid \\
\hline
\end{tabular}

Data dari kuesioner/angket keterbacaan, efesiensi dan kepraktisan di isi oleh 30 orang, termasuk dosen dan mahasiswa. Data yang diperoleh selanjutnya dihitung dan dirata-ratakan sehingga diketahui untuk kemenarikan rata-rata 3,3 dikatgorikan menarik, untuk keterbacaan 3,1 dikategorikan baik, untuk efesiensi di dapatkan 3,5 dikategorikan sangat efesien, dan untuk kepraktisan rata-rata 3,7 dikategorikan sangat praktis. Data tersebut disajikan sebagai berikut:

Tabel 2. Hasil Rata-rata Angket Keterbacaan, Efesiensi dan Kepraktisan

\begin{tabular}{|c|c|c|c|}
\hline No & Kriteria Penilaian & rata-rata & Ket \\
\hline 1 & Kemenarikan & 3,3 & Menarik \\
\hline 2 & Keterbacaan/Penyajian materi & 3,1 & Baik \\
\hline 3 & Efesiensi & 3,5 & Sangat efesien \\
\hline 4 & Kepraktisan & 3,7 & Sangat praktis \\
\hline
\end{tabular}

Berdasarkan hasil pretest dan postest kemampuan kognitif dari 28 mahasiswa diketahui bahwa terdapat kenaikan yang cukup besar rata-rata nilai pretest ke nilai posttest. Berdasarkan hasil pretest di dapatkan rata-rata nilai 19,85. Nilai rata-rata posttest kemampuan kognitif adalah 71,18 sehingga rata-rata perolehan nilai dari 28 mahasiswa yang mengikuti kegiatan pembelajaran adalah 51,33. berdasarkan hasil tes kemampuan kognitif sehingga booklet dikatakan sangat efesien digunakan pada pekulihan Taksonomi tumbuhan rendah khususnya materi fungi anak divisi ascomycota dan basidiomycota. 


\section{PEMBAHASAN}

Hasil validasi kelompok ahli dari 10 kriteria di dapatkan CVR dan CVI 1 yang berarti media layak untuk digunakan. Pada kriteria kesesuaian media dengan perkembangan atau cara berpikir mahasiswa dan kriteria booklet yang memotivasi di dapatkan nilai 3. Berdasarkan analisis kebutuhan mahasiswa gambaran materi yang berisikan jenis-jenis jamur makroskopis lebih mudah di ingat karena ada disekitar lingkungan mereka dan disajikan dengan gambaran yang jelas pada media lebih memotivasi. Hal ini sesuai dengan pendapat Amri \& Jafar (2016), pengetahuan mahasiswa Pendidikan Biologi tentang nama-nama latin terlihat rendah karena persentase menjawab salah lebih banyak dari yang benar, disebabkan rumitnya pengucapan nama latin dan banyak pengelompokkannya, juga sebagian yang memiliki ingatan rendah jika tidak sering diulangi.

Penggunaan bahasa dan istilah yang tepat juga dinilai baik dikarenakan mudah untuk dipahami. Bahasa yang tidak berbelit-belit langsung ditujukan pada pembahasan deskripsi gambar secara ringkas. Media booklet materi keragaman jenis jamur makroskopis di sekitar kota lubuklinggau, dapat dimanfaatkan sebagai media pendukung, untuk membantu menyampaikan materi pembelajaran, hal ini sejalan dengan pendapat salah satu validator yang menyatakan bahwa media booklet baik dan dapat digunakan sebagai media untuk membantu proses pembelajaran.

Desain dan tampilan fisik Booklet dinilai baik dan sangat baik oleh validator. resolusi gambar yang tinggi dan akurasi warna menjadikan mahasiswa mudah dalam mendeskripsi morfologi jamur dan menentukan jenis jamur bersadarkan hasil pengamatan pada media. Media booklet menarik dan dicetak menggunakan kertas kualitas foto yang baik. Kertas yang digunakan untuk mencetak suatu media harus bagus, karena kualitas kertas yang digunakan dapat mempengaruhi hasil cetakan.Hal ini sejalan dengan pendapat Susilana \& Cepi (2007) yang menyatakan bahwa salah satu kriteria media pembelajaran yang perlu diperhatikan adalah keserasian antara media dengan kualitas kertas yang digunakan.

Keakuratan materi dan kemutakhiran materi mendapatkan nilai yang baik juga dengan nilai CVR 1. Pembahasan deskripsi gambar disesuaikan dengan tujuan pembelajaran pada mahasiswa yang diharapkan setelah mahasiswa mempelajari jamur makroskopis dengan media booklet tujuan pembelajaran tersebut dapat tercapai. Di dalam media booklet untuk klasifikasi dan deskripsi hasil inventarisasi jamur makroskopis sudah jelas, di mana informasi yang sampaikan dilengkapi dengan peranan jamur, sehingga media buklet dapat membantu siswa untuk mengetahui klasifikasi serta deskripsi jamur yang ada di sekitarnya serta dapat memudahkan dalam mengetahui peranan jamur makroskopis yang terdapat di Kota Lubuklinggau pada saat ini. Hal ini juga sejalan dengan pendapat Arsyad (2014) bahwa dalam media pembelajaran harus sesuai dengan tujuan pembelajaran yang ingin dicapai. 
Dari hasil analisis angket keterbacaan, efesiensi dan kepraktisan di isi oleh 30 orang, termasuk dosen dan mahasiswa diperoleh nilai rata-rata yang tidak jauh berbeda dari setiap responden. berdasarkan data tersebut maka dapat disimpulkan bahwa media booklet baik, efisien dan praktis untuk digunakan. Berdasarkan hasil pembelajaran media booklet sangat membantu untuk meningkatkan pengetahuan mahasiswa terutama dari segi kognitif.

Media booklet dengan tampilan yang banyak gambar, warna serta tulisan dengan menggunakan ukuran dan jenis huruf yang sesuai dan dapat dibaca dengan baik membuat tampilan booklet menjadi lebih menarik, sehingga dapat digunakan untuk menarik perhatian belajar dan membuat pendeskripsian lebih baik dari penjelasan sehingga isi pembelajaran tersampaikan dengan baik. Sesuai pendapat Arsyad (2014) bahwa informasi yang terkandung dalam media pembelajaran dapat melahirkan minat dan motivasi belajar. Hal ini didukung oleh pendapat Pralisputri, et al. (2016) bahwa siswa cenderung menyukai bacaan yang menarik dengan sedikit uraian dan banyak gambar/warna. Berdasarkan hasil validasi, menurut validator media booklet ini baik dan dapat dijadikan referensi untuk membantu proses pembelajaran.

\section{SIMPULAN}

Booklet yang dikembangkan dinyatakan layak digunakan, booklet dikategorikan menarik, keterbacaan baik, efisien serta praktis untuk digunakan. Berdasarkan hasil tes kemampuan kognitif, booklet dikatakan sangat efesien digunakan.

\section{DAFTAR PUSTAKA}

Amri \& Jafar. (2016). Analisis Kesulitan Mahasiswa Menghafal Nama-Nama Latin di Program Studi Pendidikan Biologi Angkatan 2014 FKIP Muhammadiyah Parepare. Jurnal Biotek. 07 (08); 262-277

Annisa I., Hanna A.E., \& Wahdina. (2017). Keanekaragaman Jenis Jamur Makroskopis di Arboretum Slyvia Universitas Tanjungpura (Spesies Diversity of Macroskopic Fungi at Arboretum Slyvia Universitas Tanjungpura. Tanjungpura, Indonesia, Jurnal Hutan Lestari, 5(4); 969977.

Arini, D.I.D., Margarettha C., \& Julianus K. (2019). The Macrofungi Diversity and Their Potential Utilization In Tangale Nature Reserve Gorontalo Province (Keragaman Jenis Jamur Makro dan Peluang Pemanfaatannya di Cagar Alam Tangale Provinsi Gorontalo). Bogot, Indonesia, Jurnal Ilmuilmu Hayati, 18(1); 109-115.

Arsyad, A. (2014). Media Pembelajaran. Jakarta: Rajawa Pers.

Pralisaputri, K. R., Heribertus. S., \& Chatarina. M. (2016). Pengembangan Media Booklet Berbasis Sets Pada Materi Pokok Mitigasi Dan Adaptasi Bencana Alam Untuk Kelas X SMA. Jurnal GeoEco. Vol 2(2); 147-154.

Bernardin \& Russel, 1993. Human Resource Management. Jersey : International Editions Upper Saddle River, Prentice Hall 
Septiwiharti, L. (2015). Pengembangan Bahan Ajar Berbentuk Booklet Sejarah Indonesia pada Materi Pertempuran Lima Hari di Semarang terhadap Minat Belajar Siswa Kelas XI IPS SMA Negeri 1 Semarang Tahun Ajaran 2014/2015. Skripsi. Semarang: Jurusan Geografi Universitas Negeri Semarang

Sugiyono. (2012). Metode Penelitian Kuantitatif Kualitatif dan R\&D. Bandung: Alfabeta

Susilana, R \& Cepi. R. (2007). Media Pembelajaran. Bandung: Wacana Prima. 